\title{
Cloacibacillus evryensis gen. nov., sp. nov., a novel asaccharolytic, mesophilic, amino-acid-degrading bacterium within the phylum 'Synergistetes', isolated from an anaerobic sludge digester
}

\author{
Correspondence \\ Abdelghani Sghir \\ sghir@genoscope.cns.fr
}

\author{
Akila Ganesan, 1,2 Sébastien Chaussonnerie,, ${ }^{1,2}$ Anne Tarrade,, \\ Catherine Dauga, ${ }^{5}$ Théodore Bouchez, ${ }^{6}$ Eric Pelletier, ${ }^{1,2}$ Denis Le \\ Paslier $^{1,2}$ and Abdelghani Sghir ${ }^{1,2,7}$ \\ ${ }^{1}$ CEA-Genoscope, 2 Rue Gaston Crémieux, 91057 Evry, France \\ ${ }^{2}$ CNRS-UMR 8030, 2 Rue Gaston Crémieux, 91057 Evry, France \\ ${ }^{3}$ Laboratoire de Neurogénétique Moléculaire, INSERM, U798, Evry 91057, France \\ ${ }^{4}$ Université Paris XI, France \\ ${ }^{5}$ Genopole de l'Institut Pasteur, Paris, France \\ ${ }^{6}$ Cemagref, Hydrosystèmes et Bioprocédés, Parc de Tourvoie, BP 44, 92163 Antony Cedex, \\ France \\ ${ }^{7}$ Université d'Evry Val d'Essonne, 2 Rue Gaston Crémieux, 91057 Evry, France
}

Proteins, as well as carbohydrates and lipids, comprise a major part of the organic load in anaerobic sludges and wastewaters. For example, the protein component of dairy wastewater and domestic sewage is reportedly greater than

Abbreviations: CFA, cellular fatty acid; DHP, 3,4-dihydroxypyridine; SGOs, Synergistes group of organisms; VFA, volatile fatty acid; WWTP, wastewater treatment plant.

The GenBank/EMBL/DDBJ accession number for the 16S rRNA gene sequence of Cloacibacillus evryensis strain $158^{\top}$ is CU463952.
$40 \%$ (Ramsay \& Pullammanappallil, 2001). Protein hydrolysis in anaerobic environments has not been well studied except in the animal gut, e.g. the rumen (Debroas \& Blanchart, 1993), and has been restricted to molecular inventories in protein-containing wastewaters (Tang et al., 2005). The major difference between protein degradation in the rumen and in anaerobic digesters is that, in the rumen, the ruminal bacteria (both saccharolytic and asaccharolytic) grow on amino acids and peptides as major 
energy substrates (Eschenlauer et al., 2002). In anaerobic reactors, however, proteolytic bacteria predominantly mediate protein degradation and the process involved is energy yielding (Ramsay \& Pullammanappallil, 2001).

Under methanogenic conditions, proteins are hydrolysed to peptides and amino acids, which are subsequently fermented to volatile fatty acids (VFAs) and finally to methane and $\mathrm{CO}_{2}$ by mixed microbial populations. Species from genera such as Clostridium (Paster et al., 1993), Peptostreptococcus (Cato et al., 1983), Acidaminobacter (Stams \& Hansen, 1984), Aminomonas (Baena et al., 1999), Aminobacterium (Baena et al., 1998, 2000), Thermanaerovibrio (Zavarzina et al., 2000; Guangsheng et al., 1992), Eubacterium (Zindel et al., 1988), Dethiosulfovibrio (Magot et al., 1997), Aminiphilus (Díaz et al., 2007), Thermovirga (Dahle \& Birkeland, 2006), Jonquetella (Jumas Bilak et al., 2007) and Synergistes (Allison et al., 1992) have been shown to degrade amino acids anaerobically.

In the last edition of Bergey's Manual of Systematic Bacteriology (Garrity \& Holt, 2001), the Synergistes group under the class Deferribacteres was represented by a number of genera incertae sedis, whose taxonomic positions have not been well-defined, with only one described phylotype, namely Synergistes jonesii. Using 16S rRNA gene targeted PCR assays, Godon et al. (2005) explored 93 anaerobic environments and reported that members of the Synergistes group of organisms (SGOs) were present in $95 \%$ of the ecosystems analysed and the sequences formed separate phylogenetic groups, although their proportion was generally below $1 \%$. Also, Horz et al. (2006) have found that SGOs are ubiquitous in humans and have been detected in various infectious diseases. They identified clinically relevant isolates that make up three unique clusters that apparently occupy their own individual ecological niches within the human body such as peritoneal fluid, soft tissues and periodontal pockets, the latter having no isolated representatives. Although several isolates from human clinical samples have been added to the list recently (Vartoukian et al., 2007; Jumas-Bilak et al., 2007), to date, $S$. jonesii is the only isolate among the SGOs that has been studied and fully characterized (Allison et al., 1992). Also, there is no isolated representative of the SGOs from anaerobic digesters; thus, the origin and role of these organisms in wastewater treatment plants (WWTPs) remain unknown. In this paper, the isolation and description of strain $158^{\mathrm{T}}$, which emerges as a novel member in the phylogenetic line represented by the genus Synergistes, from a mesophilic anaerobic digester of a WWTP are reported.

The bacterial strain described in this study was isolated from a mesophilic anaerobic digester of a WWTP treating municipal wastewater in Evry (250 000 population equivalents), $35 \mathrm{~km}$ south of Paris, France. The digester working parameters were: temperature, $33{ }^{\circ} \mathrm{C} ; \mathrm{pH}, 7.2$; and retention time, 37.5 days.
The Hungate technique (Hungate, 1969) was used for strain isolation. The basal medium used in the study contained $\left(1^{-1}\right) 3 \mathrm{~g} \mathrm{KH}_{2} \mathrm{PO}_{4}, 3 \mathrm{~g} \mathrm{~K}_{2} \mathrm{HPO}_{4}, 6 \mathrm{~g} \mathrm{NaCl}, 6 \mathrm{~g}$ $\left(\mathrm{NH}_{4}\right)_{2} \mathrm{SO}_{4}, 0.6 \mathrm{~g} \mathrm{CaCl}_{2}, 1.23 \mathrm{~g} \mathrm{MgSO}_{4} .7 \mathrm{H}_{2} \mathrm{O}$ and $1 \mathrm{~g}$ sodium citrate supplemented with $2 \mathrm{~g}$ yeast extract, $10 \mathrm{~g}$ Casamino acids and $10 \mathrm{ml}$ trace element solution (Balch et al., 1979). The $\mathrm{pH}$ was adjusted to 7.0 with $10 \mathrm{M} \mathrm{KOH}$. The medium was boiled under $\mathrm{O}_{2}$-free $\mathrm{N}_{2}$ gas, cooled, sparged with $\mathrm{N}_{2} / \mathrm{CO}_{2}(80: 20, \mathrm{v} / \mathrm{v})$, autoclaved at $121{ }^{\circ} \mathrm{C}$ for $20 \mathrm{~min}$ and reduced with sterile sulfide/cysteine solution prior to inoculation. Enrichments were incubated at $33{ }^{\circ} \mathrm{C}$ and examined for growth with a phase-contrast microscope. Enrichment cultures were transferred periodically into fresh medium with $10 \%(\mathrm{v} / \mathrm{v})$ inocula. Bacterial growth was evident on Casamino acids-based medium at $33{ }^{\circ} \mathrm{C}$ after 5-7 days of growth under anaerobic conditions. Microscopic examination of this primary enrichment culture revealed micro-organisms with diverse morphologies (data not shown), but after several subcultures, small rod-shaped cells were dominant. Isolation was performed in plates with the same medium solidified with agar $(2 \%)$ and incubated in anaerobic jars at $33{ }^{\circ} \mathrm{C}$ with $\mathrm{N}_{2} / \mathrm{CO}_{2}(80: 20, \mathrm{v} / \mathrm{v})$ as gas phase at $2 \mathrm{~atm}(203 \mathrm{kPa})$ pressure. After 10 days incubation, small (about $2 \mathrm{~mm}$ in diameter), light brown, transparent, lens-shaped colonies with smooth margins appeared predominantly on the solid agar. Isolates were purified by repeated isolations until deemed to be axenic. One of the purified strains, designated strain $158^{\mathrm{T}}$, was taken up for further characterization. Subsequent routine culturing of strain $158^{\mathrm{T}}$ was performed using basal medium containing $1 \%(\mathrm{w} / \mathrm{v})$ Casamino acids and $0.2 \%(\mathrm{w} / \mathrm{v})$ yeast extract.

Light microscopy was performed using a Zeiss axioplan phase-contrast microscope. Cells of strain $158^{\mathrm{T}}$ grown in Casamino acid medium were non-motile rods, occurring singly or in pairs (Fig. 1a). Cells were variable in size, with longer cells $(2.0-3.0 \times 0.8-1.0 \mu \mathrm{m})$ being observed in older cultures. Long chains were observed in 15-day-old cultures. Motility and spores were never observed and the culture did not survive heat treatment for $2 \mathrm{~h}$ at $80^{\circ} \mathrm{C}$. For electron microscopic studies, the culture was centrifuged at $3000 \mathrm{~g}$ for $6 \mathrm{~min}$ at $4{ }^{\circ} \mathrm{C}$, the supernatant was discarded and the pellet was fixed in $3 \%$ glutaraldehyde in $0.1 \mathrm{M}$ phosphate buffer ( $\mathrm{pH} 7.4$ ) for $2 \mathrm{~h}$ at room temperature. Samples were then post-fixed in $1 \%$ osmium tetroxide for $1 \mathrm{~h}$ and washed again in buffer prior to being dehydrated in an ascending gradient of ethanol [50, 70, 80, 90, 95 and $100 \%(\mathrm{v} / \mathrm{v})]$. Finally, they were embedded in Epon resin. Ultrathin sections were stained with $2 \%(\mathrm{w} / \mathrm{v})$ uranyl acetate and examined with a Tecnai F20 transmission electron microscope (Philips) operating at $200 \mathrm{kV}$. Cells of strain $158^{\mathrm{T}}$ stained Gram-negative and ultrathin sections revealed a typical multilayered Gram-negative cell wall structure (Fig. 1b).

Growth experiments were conducted in duplicate in basal medium containing $1 \%(\mathrm{w} / \mathrm{v})$ Casamino acids and $0.2 \%$ $(\mathrm{w} / \mathrm{v})$ yeast extract. All media were inoculated $[10 \%(\mathrm{v} / \mathrm{v})]$ 

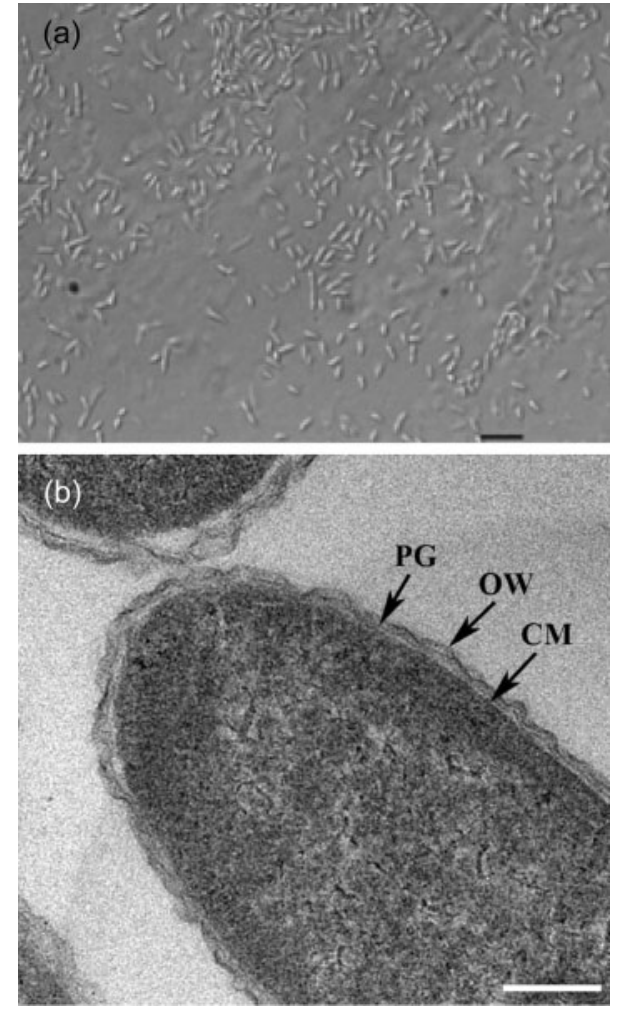

Fig. 1. (a) Phase-contrast photomicrography of cells from the exponential growth phase of strain $158^{\top}$; bar, $5 \mu \mathrm{m}$. (b) Transmission electron micrograph of ultrathin section of cells of strain $158^{\top}$ showing a typical multilayered Gram-negative cell-wall structure (OW, outer cell wall; PG, peptidoglycan layer; CM, cytoplasmic membrane); bar, $0.2 \mu \mathrm{m}$.

with late phase exponential cultures grown on Casamino acids and yeast extract. Strain $158^{\mathrm{T}}$ was a strict anaerobe, as shown by its inability to grow on Casamino acid agar under aerobic conditions. Under anaerobic conditions, the addition of $0.2 \%$ yeast extract enhanced growth, although growth occurred even in the absence of yeast extract. For $\mathrm{pH}$ studies, the medium was adjusted with anaerobically prepared stock solutions of $1 \mathrm{M} \mathrm{HCl}$ or $10 \%(w / v) \mathrm{NaOH}$ to initial $\mathrm{pH}$ values of 4.0-10.0. The $\mathrm{pH}$ range for growth at $37{ }^{\circ} \mathrm{C}$ was $6.5-10.0$, with optimum growth at $\mathrm{pH}$ 7.0-7.5. Growth at different temperatures was determined at 15$55{ }^{\circ} \mathrm{C}$. The temperature range for growth at $\mathrm{pH} 7.0$ was $20-50{ }^{\circ} \mathrm{C}$, with optimal growth at $37-40{ }^{\circ} \mathrm{C}$. The doubling time under optimal conditions on Casamino acid medium was $15 \mathrm{~h}$. $\mathrm{NaCl}$ requirements for growth were tested at concentrations between 0.1 and $2.0 \%(\mathrm{w} / \mathrm{v})$ by weighing $\mathrm{NaCl}$ directly into vials before dispensing the medium. Strain $158^{\mathrm{T}}$ tolerated up to $0.7 \% \mathrm{NaCl}$ for growth, but growth was inhibited at higher concentrations.

Substrate utilization was determined in triplicate on prereduced basal medium with $0.2 \%(\mathrm{w} / \mathrm{v})$ yeast extract and $\mathrm{N}_{2}$ as the gas phase. Soluble substrates were added from sterilized anaerobically prepared stock solutions (1 M), whereas insoluble substrates were added directly to the vial before the media was dispensed. Growth was measured at $600 \mathrm{~nm}$ in an Ultraspec 2000 (Pharmacia Biotech) spectrophotometer. Head-space gas analysis was performed using a micro GC (CP4900; Varian) equipped with four parallel chromatographic lines (two molecular sieve 5A, a poraplot $\mathrm{Q}$ and volamine columns) coupled with a thermo-conductivity detector. The poraplot $\mathrm{Q}$ column was used for $\mathrm{CO}_{2}, \mathrm{~N}_{2} \mathrm{O}$ and $\mathrm{H}_{2} \mathrm{~S}$ (helium as carrier gas, column temperature of $30{ }^{\circ} \mathrm{C}$, injector temperature of $50{ }^{\circ} \mathrm{C}$ ), the first molecular sieve column was for $\mathrm{N}_{2}$ and $\mathrm{CH}_{4}$ (helium as carrier gas, column temperature of $55{ }^{\circ} \mathrm{C}$, injector temperature of $50{ }^{\circ} \mathrm{C}$ ), the second molecular sieve was for $\mathrm{H}_{2}$ (argon as carrier gas, column temperature of $55{ }^{\circ} \mathrm{C}$, injector temperature of $50{ }^{\circ} \mathrm{C}$ ) and the volamine was for $\mathrm{NH}_{3}$ (helium as carrier gas, column temperature of $55{ }^{\circ} \mathrm{C}$, injector temperature of $50{ }^{\circ} \mathrm{C}$ ). The standard calibration was made with gas mixtures containing $(\mathrm{v} / \mathrm{v})$ $0.5 \% \mathrm{H}_{2} \mathrm{~S}, 3 \% \mathrm{~N}_{2} \mathrm{O}, 40 \% \mathrm{CO}_{2}, 50 \% \mathrm{CH}_{4}, 5 \% \mathrm{H}_{2}$ and $6.5 \% \mathrm{~N}_{2}$ (Air Products). VFAs - acetic, butyric, propionic and valeric acids - were analysed by GC (Thermoquest TRACE GC2000) equipped with a flame-ionization detector and a DB-WAXetr column (length $30 \mathrm{~m}$, inner diameter $0.53 \mathrm{~mm}$, film thickness $1 \mu \mathrm{m}$ ). Injector and detector temperatures were $230{ }^{\circ} \mathrm{C}$ and $300{ }^{\circ} \mathrm{C}$, respectively. Helium $\left(4 \mathrm{ml} \mathrm{min}^{-1}\right)$ was the carrier gas. Growth and product formation were analysed after 2-3 weeks of incubation at $37{ }^{\circ} \mathrm{C}$. Table 1 shows the substrates used by strain $158^{\mathrm{T}}$ and the end products formed. Growth was enhanced by yeast extract and strain $158^{\mathrm{T}}$ fermented histidine, arginine, lysine, serine and tryptophan $(10 \mathrm{mM}$ each). Poor growth was observed on alanine, glutamate, aspartate, proline, glycine, cysteine and phenylalanine, whereas no growth was observed on isoleucine, leucine, valine, threonine, methionine, glutamine or asparagine. Strain $158^{\mathrm{T}}$ was also able to grow on complex substrates $(0.5 \%, \mathrm{w} / \mathrm{v})$ such as brain-heart infusion $(\mathrm{BHI})$, tryptone and yeast extract, but not on phytone-peptone or tryptic soy broth. None of the sugars, organic acids or alcohols (10 $\mathrm{mM}$ each) tested were utilized apart from mannose, rhamnose and $\alpha$-ketoglutarate, although only faint growth was observed on these. Also, strain $158^{\mathrm{T}}$ did not grow on non-protein amino acids such as mimosine and 3,4dihydroxypyridine (DHP) at a final concentration of $10 \mathrm{mM}$.

The trait of degrading proteinaceous compounds alone observed in strain $158^{\mathrm{T}}$ is a property shared with only a few members of the 'Firmicutes', such as Clostridium pascui, C. acetireducens, C. litorale, C. sticklandii, C. aminophilum, Sedimentibacter hydroxybenzoicum (formerly Clostridium hydroxybenzoicum), Peptostreptococcus anaerobius, Acidaminobacter hydrogenoformans, Eubacterium acidaminophilum, Anaeromusa acidaminophila (Baena et al., 1999), and those in the phylum 'Synergistetes', namely Aminomonas paucivorans, Aminobacterium colombiense, Aminobacterium mobile, Dethiosulfovibrio peptidovorans, 
Table 1. Fermentation of substrates that support growth of strain $158^{\top}$ in pure culture

Poor growth was observed on alanine, glutamate, aspartate, proline, glycine, cysteine and phenylalanine and acetate levels above those of control were present. Tubes containing basal medium, $0.2 \%(\mathrm{w} / \mathrm{v})$ yeast extract and inoculum, but lacking substrates were used as controls.

\begin{tabular}{|c|c|c|c|c|c|c|c|}
\hline \multirow[t]{2}{*}{ Substrate } & \multicolumn{6}{|c|}{ Products $^{\star}$} & \multirow{2}{*}{$\begin{array}{c}\text { Maximum } \\
\mathrm{OD}_{600}\end{array}$} \\
\hline & Acetic acid & Propionic acid & Butyric acid & Valeric acid & $\mathrm{CO}_{2} \dagger$ & $\mathbf{H}_{2} \dagger$ & \\
\hline Casamino acids $(1 \%)$ & 36.3 & 2.01 & 2.76 & 0.53 & 22 & 3.5 & 0.768 \\
\hline $\mathrm{BHI}(0.5 \%)$ & 23.26 & 3.53 & 9.44 & 1.15 & 3.4 & 1.4 & 0.76 \\
\hline Tryptone $(0.5 \%)$ & 17.78 & 2.2 & 5.71 & 0.74 & 4.5 & 4.5 & 0.133 \\
\hline Arginine $(10 \mathrm{mM})$ & 27.53 & 0 & 55.6 & 0 & 5.9 & 4.1 & 0.162 \\
\hline Histidine (10 mM) & 44.06 & 2.74 & 2.09 & 3.53 & 3.8 & 3.0 & 0.317 \\
\hline $\begin{array}{l}\text { Arginine }+ \text { histidine } \\
(10+20 \mathrm{mM})\end{array}$ & 4.9 & 0.76 & 4.95 & 0 & 6.4 & 4.7 & 0.105 \\
\hline Lysine $(10 \mathrm{mM})$ & 18.02 & 0.46 & 1.46 & 0 & 2.2 & 4.9 & 0.10 \\
\hline Serine $(10 \mathrm{mM})$ & 19.43 & 0.49 & 3.6 & 0.75 & 3.3 & 4.8 & 0.103 \\
\hline Tryptophan $(10 \mathrm{mM})$ & 22.43 & 0 & 0 & 0 & 1.8 & 1.3 & 0.092 \\
\hline
\end{tabular}

*All values were corrected for the small amount of acetate formed in the control tubes. Experiments were conducted in triplicate and mean values (in $\mathrm{mM}$, except where indicated) are given; standard deviations were always within $5 \%$ of the mean value.

$\dagger$ Values represent percentages ( $\mathrm{v} / \mathrm{v})$ in the gas phase. Trace amounts of ammonia were also detected for some substrates; the remaining gas is $\mathrm{N}_{2}$ already present in the gas phase.

Jonquetella anthropi and S. jonesii, etc. (Vartoukian et al., 2007). Very little is understood about biochemical pathways operating in obligately anaerobic aminolytic bacteria. Strain $158^{\mathrm{T}}$ fermented arginine to acetate and butyrate, whereas $S$. jonesii produced ornithine and citrulline in addition to acetate and butyrate (McSweeny et al., 1993); Thermanaerovibrio acidaminovorans fermented arginine to acetate and propionate only in co-culture with Methanobacterium thermoautotrophicum (Guangsheng et al., 1992), whereas acetate, formate and ornithine were reported for Aminomonas paucivorans (Baena et al., 1999). Strain $158^{\mathrm{T}}$ degraded histidine to acetate, propionate, butyrate and valerate. This is different from the situations observed in S. jonesii (McSweeny et al., 1993), which ferments histidine to propionate, acetate, ornithine and butyrate, and Aminomonas paucivorans, which ferments histidine to acetate and formate (Baena et al., 1999). However, the presence of valerate as one of the fermentation products of histidine has not been reported up till now, although this could have close similarities with the scheme proposed for fatty acid elongation in the rumen bacterium Eubacterium pyruvativorans (Wallace et al., 2004). It is worthwhile to mention here that isovalerate was observed as one of the end products of fermentation of trypticase-glucose-yeast extract broth in J. anthropi, another member of the phylum 'Synergistetes' (JumasBilak et al., 2007). The conversion of lysine to acetate and butyrate (Table 1) by strain $158^{\mathrm{T}}$ suggests a pattern similar to that reported for anaerobic asaccharolytic Gram-positive rods such as Clostridium peptidovorans (Mechichi et al., 2000) and species of the genus Eubacterium that inhabit periodontal pockets (Uematsu et al., 2003). These microorganisms produce ATP by degrading lysine to acetate as observed from their acetate kinase activities (Uematsu et al., 2003). Minor amounts of propionate were also detected during the fermentation of lysine by strain $158^{\mathrm{T}}$ and, hence, further investigation into lysine degradation by this strain is required. Serine was fermented to acetate and butyrate (Table 1), with minor amounts of propionate and valerate, similar to that reported for a Gram-negative coccus (strain LC3) isolated from the rumen of sheep (Lewis \& Elsden, 1955). This again is of considerable interest as strain $158^{\mathrm{T}}$ and LC3 produce VFAs longer than butyrate. Clearly, the metabolism of serine by strain $158^{\mathrm{T}}$ requires further investigation. Growth on tryptophan was only moderate and acetate appeared to be the only fermentation product.

The effect of different gas phases on growth of the isolate was tested on the substrates that supported growth of strain $158^{\mathrm{T}}$. An $80 \%$ hydrogen atmosphere (supplied as $80: 20$ $\left.\mathrm{H}_{2} / \mathrm{CO}_{2}\right)$ at $2 \mathrm{~atm}(203 \mathrm{kPa})$ pressure inhibited growth of strain $158^{\mathrm{T}}$ on Casamino acid medium to a minor extent, whereas growth in nitrogen or $\mathrm{N}_{2} / \mathrm{CO}_{2}$ was not inhibited. Growth was not inhibited on amino acids under a hydrogen atmosphere. The electron acceptors nitrate, sulfate, thiosulfate (all at $10 \mathrm{mM})$, sulfite $(2 \mathrm{mM})$ and fumarate $(20 \mathrm{mM})$ were tested on all substrates. The addition of various electron acceptors did not increase the range of amino acids utilized and did not significantly improve growth on alanine, arginine, histidine, lysine or serine with respect to controls. Amino acid degradation via the Stickland reaction was determined in the basal medium containing the following amino acid couplets as electron donors and acceptors, respectively $(10 \mathrm{mM} / 20 \mathrm{mM})$ : alanine/arginine, alanine/proline, alanine/serine, alanine/ glycine, alanine/tryptophan, leucine/glycine, isoleucine/ 
glycine, valine/glycine and arginine/histidine. Strain $158^{\mathrm{T}}$ did not perform the Stickland reaction when grown on any of the amino acid couplets tested. Even though growth was observed on arginine/histidine, it was less than that on each of the individual amino acids (Table 1).

Antibiotic resistance was determined in mineral base medium with $0.2 \%(\mathrm{w} / \mathrm{v})$ yeast extract at $\mathrm{pH} 7.0$ and $37{ }^{\circ} \mathrm{C}$. Antibiotics were filter-sterilized and the following concentrations were tested per $50 \mathrm{ml}$ medium: penicillin (10 mg), ampicillin (10 mg), kanamycin (10 mg) and vancomycin $(5 \mu \mathrm{g})$. Growth of strain $158^{\mathrm{T}}$ was not inhibited by vancomycin, although it was inhibited in the presence of penicillin, ampicillin and kanamycin. The DNA $\mathrm{G}+\mathrm{C}$ content of strain $158^{\mathrm{T}}$ was determined by the DSMZ, Braunschweig, Germany, as described by Mesbah et al. (1989). The method involves enzymic degradation of DNA and separation of the nucleosides by reverse-phase HPLC. The DNA G + C content of strain $158^{\mathrm{T}}$ was $55.8 \mathrm{~mol} \%$.

The cellular fatty acid (CFA) and polar lipid composition were determined by the Identification Service of the DSMZ and B. J. Tindall, DSMZ, Braunschweig, Germany, by GC and two-dimensional TLC methods, respectively. The major CFAs (Table 2) of strain $158^{\mathrm{T}}$ were iso- $\mathrm{C}_{15: 0}$ $(16.63 \%)$, iso- $\mathrm{C}_{15: 0} \quad 3-\mathrm{OH} \quad(12.41 \%)$ and $\mathrm{C}_{17: 1} \omega 6 c$ $(9.46 \%)$; its closest relative, $S$. jonesii, showed different CFA ratios and lacked certain CFAs. CFAs in strain $158^{\mathrm{T}}$ were compared by the Sherlock Microbial Identification (MIDI) system to the existing database on the basis of its unique fatty acid profile, but no matches to any known bacterial CFA profiles were found. This supports the affiliation of strain $158^{\mathrm{T}}$ to a new genus. The polar fatty acid profile of strain $158^{\mathrm{T}}$ (data not shown) revealed diphosphatidylglycerol, phosphatidylglycerol, phosphatidylethanolamine and phosphatidylmonomethylamine.

Genomic DNA was extracted from the liquid enrichment of the isolate as described by Chouari et al. (2003). The universal bacterial primers $008 \mathrm{~F}$ and $1390 \mathrm{R}$ were used to obtain a PCR product of approximately $1.4 \mathrm{~kb}$. DNA amplification, PCR thermal profiling and sequencing were performed as described by Chouari et al. (2003). The $16 \mathrm{~S}$ rRNA gene sequence $(1308 \mathrm{bp})$ of strain $158^{\mathrm{T}}$ corresponded to positions 38-1384 of the Escherichia coli $16 \mathrm{~S}$ rRNA gene and was compared with sequences from the complete EMBL nucleotide database. Sequences of nearest neighbours of cultured species from the EMBL database with the best BLAST scores were imported into the ARB database set (www.arb-home.de) and aligned automatically. The resulting alignments were checked manually and corrected where necessary. BLAST searches in international databases revealed that the most closely related sequences to that of strain $158^{\mathrm{T}}$ were the $16 \mathrm{~S}$ rRNA gene from a bacterium, ADV66, isolated from human vaginal flora (GenBank accession no. EF468684) and from Synergistes spp. isolated from human blood (EF551160, EF551161, EF551162) and peritoneal fluid samples (DQ412721, DQ412717, DQ412718) (Horz et al., 2006) (Fig. 2).
Table 2. Cellular fatty acid profiles (\%) of strain $158^{\top}$ and $S$. jonesii

$\omega$, Position of the double bond from the methyl end; $c$, cis isomer; cyc, cyclopropane; DMA, dimethyl acetal. Major fatty acids are given in bold type.

\begin{tabular}{|c|c|c|}
\hline Fatty acid & Strain $158^{\mathrm{T}}$ & S. jonesii \\
\hline \multicolumn{3}{|l|}{ Saturated: } \\
\hline $\mathrm{C}_{12: 0}$ & 0.2 & - \\
\hline $\mathrm{C}_{13: 0}$ & 2.22 & 2.0 \\
\hline iso- $\mathrm{C}_{13: 0}$ & 6.51 & 6.0 \\
\hline $\mathrm{C}_{14: 0}$ & 0.34 & 1.0 \\
\hline $\mathrm{C}_{14: 0} \mathrm{DMA}$ & 0.63 & - \\
\hline$C_{15: 0}$ & 2.63 & 9.0 \\
\hline iso- $\mathrm{C}_{15: 0}$ & 16.63 & 3.0 \\
\hline anteiso- $\mathrm{C}_{15: 0}$ & 0.36 & 1.0 \\
\hline $\mathrm{C}_{16: 0}$ & 2.05 & 3.0 \\
\hline $\mathrm{C}_{17: 0}$ & 6.7 & 14.0 \\
\hline iso- $\mathrm{C}_{17: 0}$ & 5.62 & 3.0 \\
\hline $\mathrm{C}_{17: 0}$ DMA & 0.83 & - \\
\hline $\mathrm{C}_{18: 0}$ & 1.22 & 3.0 \\
\hline \multicolumn{3}{|l|}{ Unsaturated: } \\
\hline $\mathrm{C}_{15: 1} \omega 6 c$ & 2.65 & 1.0 \\
\hline $\mathrm{C}_{16: 1} \omega 7 c$ & 2.44 & 1.0 \\
\hline $\mathrm{C}_{17: 1} \omega 6 c$ & 9.46 & 9.0 \\
\hline iso- $\mathrm{C}_{17: 1}$ & - & 1.0 \\
\hline $\mathrm{C}_{18: 1} \omega 5 c$ & 5.5 & 1.0 \\
\hline $\mathrm{C}_{19: 1} \omega 12 c$ & 0.65 & 7.0 \\
\hline iso- $\mathrm{C}_{19: 1}$ & - & 1.0 \\
\hline \multicolumn{3}{|l|}{ Hydroxy: } \\
\hline $\mathrm{C}_{13: 0} 3-\mathrm{OH}$ & - & 1.0 \\
\hline $\mathrm{C}_{14: 0} 3-\mathrm{OH}$ & - & 1.0 \\
\hline iso- $\mathrm{C}_{15: 0} 3-\mathrm{OH}$ & 12.41 & 7.0 \\
\hline $\mathrm{C}_{15: 0} 3-\mathrm{OH}$ & 4.6 & 8.0 \\
\hline $\mathrm{C}_{16: 0} 3-\mathrm{OH}$ & 0.49 & - \\
\hline \multicolumn{3}{|l|}{ Cyclopropane fatty acids: } \\
\hline $\mathrm{C}_{19}$ сус 9,10 & 1.39 & 1.0 \\
\hline $\mathrm{C}_{19}$ cycl1,12 & 1.15 & - \\
\hline $\mathrm{C}_{20} \mathrm{cyc}$ & - & 14.0 \\
\hline \multicolumn{3}{|l|}{ Summed features:* } \\
\hline $\mathrm{C}_{15: 0} \mathrm{DMA} / \mathrm{C}_{14: 0} 3-\mathrm{OH}$ & 2.03 & - \\
\hline anteiso- $\mathrm{C}_{15: 0} 3-\mathrm{OH} / \mathrm{C}_{16: 1} \omega 9 c \mathrm{DMA}$ & 0.74 & - \\
\hline $\mathrm{C}_{17: 2}$ at $16.760 / \mathrm{C}_{17: 1} \omega 9 c$ & 6.81 & - \\
\hline $\mathrm{C}_{17: 1} \omega 8 c / \mathrm{C}_{17: 2}$ at 16.801 & 1.39 & - \\
\hline $\mathrm{C}_{18: 1} \omega 7 \mathrm{c} /$ unknown at $17.834 \dagger$ & 1.15 & - \\
\hline Unknown at $18.622 \dagger$ & 1.16 & - \\
\hline
\end{tabular}

${ }^{*}$ Summed features represent two fatty acids that cannot be separated by GLC with the MIDI system.

$\dagger$ Unknown fatty acids have no name listed in the peak library file of the MIDI system and therefore cannot be identified; values are equivalent chain-lengths.

Strain $158^{\mathrm{T}}$ grouped with the uncultured clones of Synergistes group 8 (data not shown) from anaerobic digesters (Godon et al., 2005), albeit with only $90 \%$ similarity to the most closely related sequence, clone MLE1-42 (AF280863). 


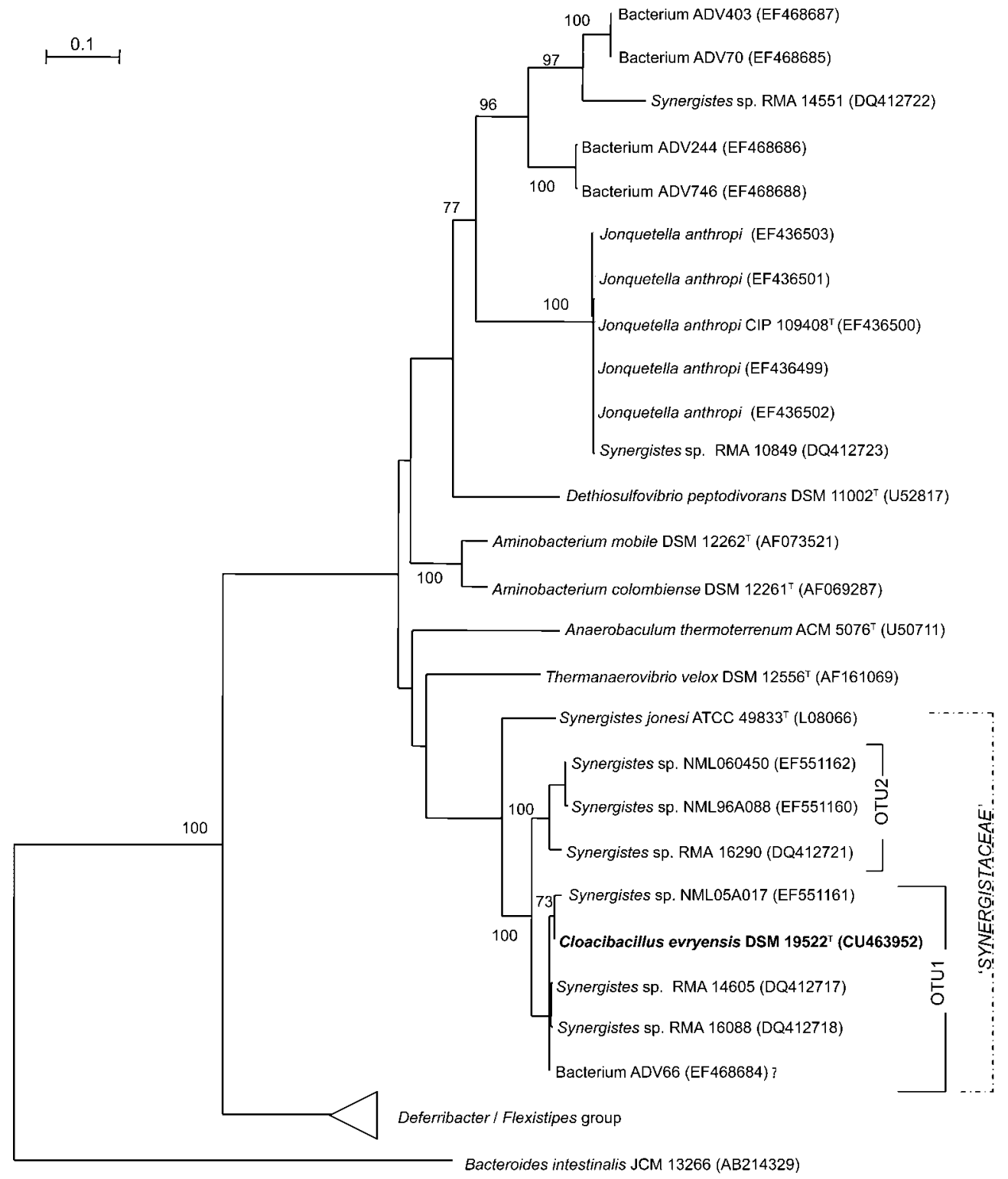

Fig. 2. Evolutionary dendrogram constructed by the neighbour-joining method showing the affiliation of strain $158^{\top}$ to its closest relatives in the GenBank database. The sequence from Bacteroides intestinalis was used as the outgroup to root the tree. Bootstrap values of 100 resamplings are shown for the closest relatives. Only bootstrap values above $70 \%$ were considered significant and reported. Bar, 10 nucleotide substitutions per 100 nucleotides.

Phylogenetic trees were constructed using the ARB program and database package. Placement was done by comparison with reference sequences representing the main lines of descent in the domain Bacteria. Phylogenetic trees based on the 16S rRNA gene sequences of cultured bacteria in the neighbourhood of strain $158^{\mathrm{T}}$ were built using three methods provided by PAUP $4.0 \mathrm{~b} 10$ software (Swofford, 2002): distance, maximum-likelihood and maximumparsimony. A strict consensus tree was drawn when multiple best trees were obtained. The delineation of species, genus and family within groups of Synergistes was proposed by using distance values of 0.03 to differentiate at the species level, 0.05 at the genus level and 0.1 at the family/class level (Schloss \& Handelsman, 2004). In the phylogenetic trees obtained with the three building methods, the cultured Synergistes spp. formed two monophyletic groups supported by high bootstrap values, rooted by the $16 \mathrm{~S}$ rRNA gene of $S$. jonesii (Fig. 2). Strain $158^{\mathrm{T}}$ was clearly included in group 'OTU1' formed by isolates NML05A017, RMA14605, RMA16088 and ADV66 of human origin. Sequences within OTU1 shared a high mean similarity value of $98.83 \%$ (or a low distance value of 
$0.015)$ and were in agreement with the criteria generally admitted to limit the species, that is, $97 \%$ similarity and a distance value of up to 0.03 . Group OTU1 had a mean similarity of $95.15 \%$ (distance value of 0.069 ) with sequences from group 'OTU2', represented by isolates NML060450, NML96A088 and RMA 16290, also of human origin. The level of similarity and distance between groups OTU1 and OTU2 was similar to that observed between Aminobacterium mobile and Aminobacterium colombiense ( $94.69 \%$ for similarity; 0.074 for distance), two species of the same genus. S. jonesii was more distantly related to the sequences in OTU1 and OTU2 (92.36 and $92.7 \%$ similarities, respectively).

Several phenotypic properties also support this conclusion (Table 3). Strain $158^{\mathrm{T}}$ shares with $S$. jonesii the ability to ferment arginine and histidine, yeast extract, BHI and Casamino acids; both are Gram-negative, non-motile, nonspore-forming rods that do not utilize carbohydrates or organic acids as carbon sources and do not perform the Stickland reaction. Strain $158^{\mathrm{T}}$ differs from S. jonesii in its $\mathrm{pH}$ range for growth, which in turn may reflect their habitats. Strain $158^{\mathrm{T}}$ was isolated from an anaerobic digester and, hence, exhibits growth in the alkaline range (up to $\mathrm{pH} 10$ ) as is observed with other species isolated from anaerobic digesters such as Aminobacterium colombiense (Baena et al., 1998) and Aminobacterium mobile (Baena et al., 2000). S. jonesii, like all other rumen bacteria has a growth range of $\mathrm{pH}$ 6.0-6.9 (Kamra, 2005). In addition to arginine and histidine, strain $158^{\mathrm{T}}$ fermented other amino acids such as lysine and serine, whereas $S$. jonesii did not (Table 2). Growth on non-protein amino acids such as mimosine or its degradation component 3,4DHP was reported as a distinctive trait of $S$. jonesii (Allison et al., 1992); however, this property was not observed in strain $158^{\mathrm{T}}$.

The low 16S rRNA gene sequence similarity levels between strain $158^{\mathrm{T}}$ and $S$. jonesii, Aminobacterium colombiense and Aminobacterium mobile (92.58, 86.31 and $86.79 \%$, respectively) and its distinctive phylogenetic position allow us to affirm strain $158^{\mathrm{T}}$ as a representative of a novel species in a new genus. Furthermore, the DNA G $+\mathrm{C}$ content of strain $158^{\mathrm{T}}$ (55.8 mol\%), which is slightly lower than that of $S$. jonesii (58 mol\%), and its unique CFA profile (Table 2) support its affiliation in a new genus. Based on $16 \mathrm{~S}$ rRNA gene sequence analysis and its phylogenetic position, it is proposed that the species represented by strain $158^{\mathrm{T}}$ be given genus status in a newly proposed family 'Synergistaceae', which encompasses groups OTU1 and OTU2 and S. jonesii (Fig. 2). According to the Bergey's system of classification (Garrity \& Holt, 2001), placement of $S$. jonesii in the phylum 'Deferribacteres' was provisional. Isolation of different Synergistes-like micro-organisms (Horz et al., 2006) and the retrieval of many other Synergistes rRNA gene sequences from different environments have allowed a thorough phylogenetic analysis of this group of micro-organisms. Our study (Fig. 2) corroborates other studies (Godon et al., 2005; Horz et al., 2006; Vartoukian et al., 2007; Jumas-Bilak et al., 2007) showing that the SGOs and related genera are reproducibly monophyletic and unaffiliated with the FlexistipesDeferribacter group and, therefore, the creation of a new phylum 'Synergistetes', as proposed by Jumas-Bilak et al. (2007), is justified.

With the isolation of strain $158^{\mathrm{T}}$, we extend our knowledge of the biodiversity of asaccharolytic amino-acid-degraders from anaerobic sludge digesters. On the basis of the phenotypic, genotypic and phylogenetic evidence presented and based on the current taxonomic guidelines, it is proposed that strain $158^{\mathrm{T}}$ represents a novel species in a new genus, Cloacibacillus evryensis gen. nov., sp. nov., in a new family 'Synergistaceae', phylum 'Synergistetes'.

\section{Description of Cloacibacillus gen. nov.}

Cloacibacillus (Clo.a'ci.ba.cil.lus. L. n. cloaca a sewer canal; L. masc. n. bacillus a small staff; N.L. masc. n. Cloacibacillus a small staff from a sewer canal).

Cells are strictly anaerobic rods, non-motile, with no flagella. Gram-negative type cell wall. Mesophilic and nonspore-forming. Neutrophilic and heterotrophic in nature. Asaccharolytic and proteolytic. Metabolism is fermentative, does not reduce any of the electron acceptors and does not perform the Stickland reaction. The major fatty acids are iso- $\mathrm{C}_{15: 0}$, iso- $\mathrm{C}_{15: 0} 3-\mathrm{OH}$ and $\mathrm{C}_{17: 1} \omega 6 c$. Members of this genus can be differentiated from other genera in the phylum 'Synergistetes' by 16S rRNA gene sequencing, CFA profiles, DNA G $+\mathrm{C}$ content and metabolic end products. The genus is affiliated to the family 'Synergistaceae' in the phylum 'Synergistetes'. The type species is Cloacibacillus evryensis.

\section{Description of Cloacibacillus evryensis sp. nov.}

Cloacibacillus evryensis (ev.ry.en.sis. N.L. masc. adj. evryensis pertaining to Evry, the origin of the isolate).

In addition to the properties listed in the genus description, the following properties are observed. Rodshaped bacterium, $2.0-3.0 \times 0.8-1.0 \mu \mathrm{m}$ in size, occurring singly or in pairs; older cells form chains. Electron microscopy reveals a cell-wall structure typical of Gramnegative bacteria. Colonies are light brown, small (about 1$2 \mathrm{~mm}$ in diameter), transparent and lens-shaped with smooth margins. Mesophilic, optimum growth temperature is $37{ }^{\circ} \mathrm{C}$ and the growth range is $20-50{ }^{\circ} \mathrm{C}$. The $\mathrm{pH}$ range for growth is 6.5-10.0, with optimum at $\mathrm{pH} 7.0$. Doubling time is $15 \mathrm{~h}$ on Casamino acid medium. Tolerates less than $0.7 \% \mathrm{NaCl}$ for growth. Growth is enhanced by yeast extract. Ferments histidine, arginine, lysine, serine, BHI, yeast extract and tryptone. No growth is observed on other amino acids or carbohydrates. Acetate, butyrate, propionate, valerate, $\mathrm{H}_{2}$ and $\mathrm{CO}_{2}$ are the usual end products of fermentation. Sensitive to penicillin, ampicillin and kanamycin, but resistant to vancomycin. 
Table 3. Differential characteristics of the genus Cloacibacillus and related genera in the phylum 'Synergistetes'

Genera: 1, Cloacibacillus (represented by Cloacibacillus evryensis gen. nov., sp. nov. strain 158 ${ }^{\mathrm{T}}$ ); 2, Synergistes [represented by S. jonesii (GenBank accession no. L08066)]; 3, Aminobacterium [Aminobacterium colombiense (AF069287) and Aminobacterium mobile (AF073521)]; 4, Aminomonas [Aminomonas paucivorans (AF072581)]; 5, Anaerobaculum [Anaerobaculum thermoterranum (U50711) and Anaerobaculum mobile (AJ243189)]; 6, Thermanaerovibrio [T. acidaminovorans (AF071414) and T. velox (AF161069)]; 7, Dethiosulfovibrio [D. peptidovorans (U52817), D. acidaminovorans (AY005466), D. russensis (AF234544) and D. marinus (AF234542)]. +, Positive; -, negative; +/-, some species are positive and some are negative; ND, not determined.

\begin{tabular}{|c|c|c|c|c|c|c|c|}
\hline Characteristic & 1 & 2 & 3 & 4 & 5 & 6 & 7 \\
\hline Habitat & $\begin{array}{c}\text { Anaerobic digester, } \\
\text { human clinical } \\
\text { samples }\end{array}$ & Goat rumen & $\begin{array}{l}\text { Anaerobic dairy } \\
\text { wastewater } \\
\text { treatment plant }\end{array}$ & $\begin{array}{l}\text { Anaerobic dairy } \\
\text { wastewater } \\
\text { treatment plant }\end{array}$ & Anaerobic digester & $\begin{array}{l}\text { Anaerobic digester, } \\
\text { cyanobacterial mat }\end{array}$ & $\begin{array}{l}\text { Saline oil wells, } \\
\text { sulfur mats }\end{array}$ \\
\hline Cell morphology & Straight rods & Rods & Rods & Curved rods & Rods & Vibrios & Vibrios \\
\hline $\begin{array}{l}\text { Optimum growth } \\
\text { temperature }\left({ }^{\circ} \mathrm{C}\right)\end{array}$ & $35-40$ & 39 & 37 & 37 & $55-60$ & $55-65$ & $28-42$ \\
\hline $\begin{array}{l}\text { DNA G + C } \\
\text { content }(\mathrm{mol} \%)\end{array}$ & 55.8 & 58 & $44-46$ & 43 & $44.0-51.5$ & $54-57$ & $50-56$ \\
\hline Motility & - & - & $+1-$ & - & $+1-$ & + & + \\
\hline Metabolism & Fermentative & Fermentative & Fermentative & Fermentative & Fermentative/respiratory & Fermentative/respiratory & Fermentative/respiratory \\
\hline Fermentation & Proteolytic & Proteolytic & Proteolytic & Proteolytic & $\begin{array}{c}\text { Proteolytic and } \\
\text { saccharolytic }\end{array}$ & $\begin{array}{c}\text { Proteolytic and } \\
\text { saccharolytic }\end{array}$ & Proteolytic \\
\hline Electron acceptors & - & $\mathrm{ND}$ & - & - & $\begin{array}{l}\text { Crotonate, thiosulfate, } \\
\text { cysteine, sulfur }\end{array}$ & Elemental sulfur & Sulfur and thiosulfate \\
\hline Stickland reaction & - & - & - & $\mathrm{ND}$ & $\mathrm{ND}$ & ND & $\mathrm{ND}$ \\
\hline $\begin{array}{l}\text { Major cellular } \\
\text { fatty acids }\end{array}$ & $\begin{array}{c}\text { iso- } \mathrm{C}_{15: 0} \text {, iso- } \mathrm{C}_{15: 0} \\
\text { 3-OH, } \mathrm{C}_{17: 1} \omega 6 c \\
\text { (lacks } \mathrm{C}_{20} \text { cyc) }\end{array}$ & $\begin{array}{c}\mathrm{C}_{17: 0,} \mathrm{C}_{20} \mathrm{cyc}, \\
\mathrm{C}_{17: 1} \omega 6 c\end{array}$ & $\mathrm{ND}$ & $\mathrm{ND}$ & $\mathrm{ND}$ & $\mathrm{ND}$ & iso- $\mathrm{C}_{15: 0}, \mathrm{C}_{18: 0^{*}}$ \\
\hline $\begin{array}{l}\text { Additional } \\
\text { features }\end{array}$ & $\begin{array}{l}\text { Some species of this } \\
\text { genus detected in } \\
\text { human clinical } \\
\text { infections }\end{array}$ & $\begin{array}{c}\text { Degrades } \\
3,4-\mathrm{DHP}\end{array}$ & $\begin{array}{l}\text { Ferments some } \\
\text { amino acids in } \\
\text { co-culture with } \\
\text { Methanobacterium } \\
\text { formicicum }\end{array}$ & $\begin{array}{c}\text { Ferments some amino } \\
\text { acids in co-culture } \\
\text { with } \\
\text { Methanobacterium } \\
\text { formicicum }\end{array}$ & $\begin{array}{l}\text { Crotonate used as } \\
\text { electron acceptor }\end{array}$ & Thermophilic & Moderately halophilic \\
\hline
\end{tabular}

${ }^{*}$ Data from Jumas-Bilak et al. (2007). 
Does not grow on non-protein amino acids such as mimosine and 3,4-DHP.

The type strain, strain $158^{\mathrm{T}} \quad\left(=\mathrm{DSM} \quad 19522^{\mathrm{T}}=\mathrm{JCM}\right.$ $\left.14828^{\mathrm{T}}\right)$, was isolated from an anaerobic digester of a WWTP in Evry, France. The DNA G $+\mathrm{C}$ content of the type strain is $55.8 \mathrm{~mol} \%$.

\section{Acknowledgements}

We thank Dr Annett Kreimeyer, CEA-Genoscope for useful discussions. Thanks are also due to the CEA-Genoscope sequencing team for their excellent technical assistance. We thank Alain Thorel, Centre des Matériaux, Ecole des Mines de Paris et CNRS UMR 7633, Evry, France, for the transmission electron microscope facility and Dr Judith Melki, Laboratoire de Neurogénétique Moléculaire, INSERM, Universités Evry et Paris XI, for technical assistance. The transmission electron microscope was supported by INSERM, Conseil Régional d'Ile de France, Ecole des Mines and Genopole. We also thank Stéphane Frenette, Martine Trouvé and Dominique Legall for providing samples from the Evry WWTP.

\section{References}

Allison, M. J., Mayberry, W. R., McSweeny, C. S. \& Stahl, D. A. (1992), Synergistes jonesii gen. nov., sp. nov.: a rumen bacterium that degrades toxic pyridinediols. Syst Appl Microbiol 15, 522-529.

Baena, S., Fardeau, M.-L., Labat, M., Ollivier, B., Thomas, P., Garcia, J.-L. \& Patel, B. K. C. (1998). Aminobacterium colombiense gen. nov. sp. nov., an amino acid-degrading anaerobe isolated from anaerobic sludge. Anaerobe 4, 241-250.

Baena, S., Fardeau, M.-L., Ollivier, B., Labat, M., Thomas, P., Garcia, J.-L. \& Patel, B. K. C. (1999). Aminomonas paucivorans gen. nov., sp. nov., a mesophilic, anaerobic, amino-acid-utilizing bacterium. Int $J$ Syst Bacteriol 49, 975-982.

Baena, S., Fardeau, M.-L., Labat, M., Ollivier, B., Garcia, J.-L. \& Patel, B. K. C. (2000). Aminobacterium mobile sp. nov., a new anaerobic amino-acid-degrading bacterium. Int J Syst Evol Microbiol 50, 259-264.

Balch, W. E., Fox, G. E., Magrum, R. J. \& Wolfe, R. S. (1979). Methanogens: re-evaluation of a unique biological group. Microbiol Rev 43, 260-296.

Cato, E. P., Johnson, J. L., Hash, D. E. \& Holdeman, L. V. (1983). Synonomy of Peptococcus glycinophilus (Cardon and Barker 1946) Douglas 1957 with Peptostreptococcus micros (Prévot 1933) Smith 1957 and electrophoretic differentiation of Peptostreptococcus micros from Peptococcus magnus (Prévot 1933) Holdeman and Moore 1972. Int J Syst Bacteriol 33, 207-210.

Chouari, R., Le Paslier, D., Daegelen, P., Ginestet, P., Weissenbach, J. \& Sghir, A. (2003). Molecular evidence for novel planctomycete diversity in a municipal wastewater treatment plant. Appl Environ Microbiol 69, 7354-7363.

Dahle, H. \& Birkeland, N. K. (2006). Thermovirga lienii gen. nov., sp. nov., a novel moderately thermophilic, anaerobic, amino-aciddegrading bacterium isolated from a North Sea oil well. Int J Syst Evol Microbiol 56, 1539-1545.

Debroas, D. \& Blanchart, G. (1993). Interactions between proteolytic and cellulolytic rumen bacteria during hydrolysis of plant cell wall protein. Reprod Nutr Dev 33, 283-288.

Diaz, C., Baena, S., Fardeau, M.-L. \& Patel, B. K. C. (2007). Aminiphilus circumscriptus gen. nov., sp. nov., an anaerobic amino- acid-degrading bacterium from an upflow anaerobic sludge reactor. Int J Syst Evol Microbiol 57, 1914-1918.

Eschenlauer, S. C. P., McKain, N., Walker, N. D., McEwan, N. R., Newbold, C. J. \& Wallace, R. J. (2002). Ammonia production by ruminal microorganisms and enumeration, isolation, and characterization of bacteria capable of growth on peptides and amino acids from the sheep rumen. Appl Environ Microbiol 68, 4925-4931.

Garrity, G. M. \& Holt, J. G. (2001). Phylum BIX. Deferribacteres phy. nov. In Bergey's Manual of Systematic Bacteriology, 2nd edn, vol. 1 (The Archaea and the Deeply Branching and Phototrophic Bacteria), pp. 465-471. Edited by D. R. Boone, R. W. Castenholz \& G. M. Garrity. New York: Springer-Verlag.

Godon, J. J., Morinière, J., Moletta, M., Gaillac, M., Bru, V. \& Delgènes, J. P. (2005). Rarity associated with specific ecological niches in the bacterial world: the 'Synergistes' example. Environ Microbiol 7, 213-224.

Guangsheng, C., Plugge, C. M., Roelofsen, W., Houwen, F. P. \& Stams, A. J. M. (1992). Selenomonas acidaminovorans sp. nov., a versatile thermophilic proton-reducing anaerobe able to grow by decarboxylation of succinate to propionate. Arch Microbiol 157, 169-175.

Horz, H. P., Citron, D. M., Warren, Y. A., Goldstein, E. J. C. \& Conrads, G. (2006). Synergistes group organisms of human origin. J Clin Microbiol 44, 2914-2920.

Hungate, R. E. (1969). A roll tube method for cultivation of strict anaerobes. Methods Microbiol 3B, 117-132.

Jumas-Bilak, E., Carlier, J. P., Jean-Pierre, H., Citron, D., Bernard, K., Damay, A., Gay, B., Teyssier, C., Campos, J. \& Marchandin, H. (2007). Jonquetella anthropi gen. nov., sp. nov., the first member of the candidate phylum 'Synergistetes' isolated from man. Int J Syst Evol Microbiol 57, 2743-2748.

Kamra, D. N. (2005). Rumen microbial ecosystem. Curr Sci 89, 124-135.

Lewis, D. \& Elsden, S. R. (1955). The fermentation of L-threonine, Lserine, L-cysteine and acrylic acid by a Gram-negative coccus. Biochem J 60, 683-692.

Magot, M., Ravot, G., Campaignolle, X., Ollivier, B., Patel, B. K. C., Fardeau, M.-L., Thomas, P., Crolet, J. L. \& Garcia, J. L. (1997). Dethiosulfovibrio peptidovorans gen. nov., sp. nov., a new anaerobic slightly halophilic, thiosulfate-reducing bacterium from corroding offshore oil wells. Int J Syst Bacteriol 47, 818-824.

McSweeny, C. S., Allison, M. J. \& Mackie, R. I. (1993). Amino acid utilization by the ruminal bacterium Synergistes jonesii strain 78-1. Arch Microbiol 159, 131-135.

Mechichi, T., Fardeau, M.-L., Labat, M., Garcia, J.-L., Verhé, F. \& Patel, B. K. C. (2000). Clostridium peptidivorans sp. nov., a peptidefermenting bacterium from an olive mill wastewater treatment digester. Int J Syst Evol Microbiol 50, 1259-1264.

Mesbah, M., Premachandran, U. \& Whitman, W. B. (1989). Precise measurement of the $\mathrm{G}+\mathrm{C}$ content of deoxyribonucleic acid by highperformance liquid chromatography. Int J Syst Bacteriol 39, 159-167.

Paster, B. J., Russell, J. B., Yang, C. M., Chow, J. M., Woese, C. R. \& Tanner, R. (1993). Phylogeny of the ammonia-producing ruminal bacteria Peptostreptococcus anaerobius, Clostridium sticklandii, and Clostridium aminophilum sp. nov. Int J Syst Bacteriol 43, 107-110.

Ramsay, I. R. \& Pullammanappallil, P. C. (2001). Protein degradation during anaerobic wastewater treatment: derivation of stoichiometry. Biodegradation 12, 247-257.

Schloss, P. D. \& Handelsman, J. (2004). Status of the microbial census. Microbiol Mol Biol Rev 68, 686-691.

Stackebrandt, E. \& Goebel, B. M. (1994). Taxonomic note: a place for DNA-DNA reassociation and $16 \mathrm{~S}$ rRNA sequence analysis in the present species definition in bacteriology. Int J Syst Bacteriol 44, 846-849. 
Stams, A. J. M. \& Hansen, T. A. (1984). Fermentation of glutamate and other compounds by Acidaminobacter hydrogenoformans gen. nov. sp. nov., an obligate anaerobe isolated from black mud. Studies with pure cultures and mixed cultures with sulfate-reducing and methanogenic bacteria. Arch Microbiol 137, 329-337.

Swofford, D. L. (2002). PAUP* beta version: Phylogenetic analysis using parsimony (and other methods), version 4. Sunderland, MA: Sinauer Associates.

Tang, Y., Shigematsu, T., Morimura, S. \& Kida, K. (2005). Microbial community analysis of mesophilic anaerobic protein degradation process using bovine serum albumin (BSA)-fed continuous cultivation. J Biosci Bioeng 99, 150-164.

Uematsu, H., Sato, N., Hossain, M. Z., Ikeda, T. \& Hoshino, E. (2003). Degradation of arginine and other amino acids by butyrate-producing asaccharolytic anaerobic Gram-positive rods in periodontal pockets. Arch Oral Biol 48, 423-429.
Vartoukian, S. R., Palmer, R. M. \& Wade, W. G. (2007). The division "Synergistes". Anaerobe 13, 99-106.

Wallace, R. J., Chaudhary, L. C., Miyagawa, E., McKain, N. \& Walker, N. D. (2004). Metabolic properties of Eubacterium pyruvativorans, a ruminal 'hyper-ammonia-producing' anaerobe with metabolic properties analogous to those of Clostridium kluyveri. Microbiology 150, 2921-2930.

Zavarzina, D. G., Zhilina, T. N., Tourova, T. P., Kuznetsov, B. B., Kostrikina, N. A. \& Bonch-Osmolovskaya, E. A. (2000). Thermanaerovibrio velox sp. nov., a new anaerobic, thermophilic, organotrophic bacterium that reduces elemental sulfur, and emended description of the genus Thermanaerovibrio. Int J Syst Evol Microbiol 50, 1287-1295.

Zindel, U., Freundenberg, W., Rieth, M., Andreesen, J. R., Schnell, J. \& Widdel, F. (1988). Eubacterium acidaminophilum sp. nov., a versatile amino acid-degrading anaerobe producing or utilizing $\mathrm{H}_{2}$ or formate. Description and enzymatic studies. Arch Microbiol 150, 254-266. 